\title{
Growth/Differentiation Factor 2
}

National Cancer Institute

\section{Source}

National Cancer Institute. Growth/Differentiation Factor 2. NCI Thesaurus. Code

C126997.

Growth/differentiation factor 2 ( $429 \mathrm{aa}, \sim 47 \mathrm{kDa}$ ) is encoded by the human GDF2 gene.

This protein is involved in the negative regulation of angiogenesis. 